\title{
ARSENIC POLLUTION CHARACTERISTICS AND VARIATION TRENDS IN YANGZONGHAI LAKE, CHINA
}

\author{
ZHANG, Y. X. ${ }^{1,2}-$ SHI, J. S. ${ }^{*}-$ LIU, J. T. ${ }^{1}-$ ZHOU, B. ${ }^{1}$ \\ ${ }^{I}$ The Institute of Hydrogeology and Environmental Geology, C.A.G.S. \\ No. 268, Zhonghuabei Street, Shijiazhuang 050061, People's Republic of China \\ (phone: + 86-311-6759-8512; fax: +86-311-6759-8661) \\ ${ }^{2}$ China University of Geosciences \\ No. 29, College Road, Haidian District, Beijing 100083, People's Republic of China \\ (phonelfax: +86-10-8232-2005) \\ *Corresponding author \\ e-mail: 124582556@qq.com; phone: +86-311-6759-8559 \\ (Received ${ }^{\text {th }}$ Jun 2019; accepted $28^{\text {th }}$ Aug 2019)
}

\begin{abstract}
In order to ascertain the status quo and variation trend of arsenic pollution in Yangzonghai Lake, China, the water samples of Yangzonghai Lake, sediment and interstitial water were collected and the total amount and morphological composition of arsenic were determined. The spatial distribution of arsenic was analyzed and the variation trends of arsenic pollution was evaluated. The results showed that the arsenic content of lake water in December 2016 was between $0.029-0.036 \mathrm{mg} / \mathrm{L}$. The arsenic content in interstitial water is generally lower than $0.005 \mathrm{mg} / \mathrm{L}$. The average content of arsenic in 0-2, 2-4, 4-6, 6$8 \mathrm{~cm}$ sediments are $50.5 \mathrm{mg} / \mathrm{kg}, 40.1 \mathrm{mg} / \mathrm{kg}, 33.6 \mathrm{mg} / \mathrm{kg}$ and $32.5 \mathrm{mg} / \mathrm{kg}$, respectively. The high arsenic area is mainly distributed in the north and south shores, and gradually decreases from the coastal areas to the lake center. As the depth increases, arsenic content in the sediment gradually decreases. The arsenic in the sediment is still mainly in residual fraction, followed by organic fraction and oxide fraction. With the passage of time, the arsenic in the sediment gradually transforms from oxide fraction and organic fraction to residual fraction. The release of arsenic in the sediment is limited and the ecological risk is minimal.
\end{abstract}

Keywords: arsenic, morphology, interstitial water, sediment, variation trend

\section{Introduction}

Arsenic is a serious pollutant with potentially harmful effects (Huang et al., 2018; Zhang et al., 2015). Due to its recalcitrance, strong biotoxicity, bioaccumulation and biomagnification effect, arsenic contamination has been attracting much attention (Barrett et al., 2019; Jakobsen et al., 2018; Romero-Freire et al., 2014). In 2008, a serious arsenic pollution incident occurred in Yangzonghai Lake, one of the nine highland lakes in Yunnan Province. From April to October 2008, the arsenic content of Yangzonghai Lake rose sharply from $5 \mu \mathrm{g} \cdot \mathrm{L}^{-1}$ to $134 \mu \mathrm{g} \cdot \mathrm{L}^{-1}$ (Bi et al., 2014), and the water quality decreased from class II to inferior class V. According to the investigation, the source of arsenic pollution derived from a chemical plant on the hill in the southwest corner of the lake. The area belongs to karst landform area. The underground of the chemical plant area is carbonate rock and caves, and the karst is strongly developed. The high-arsenic wastewater discharged by the chemical plant in violation of regulations enters the karst zone through the soil, and then enters the lake from the spring formed by the fracture of the karst zone. The pollution incident has brought a huge impact on the production and life of the surrounding residents, directly threatening drinking water safety of more than 20,000 people around, causing inconvenience to irrigation of crops around the lake. The livelihood of hundreds of fishermen on both 
sides of the river is worrying, and the surrounding tourism and holiday industry is also suffering from heavy losses, so it has aroused widespread concern in society (Wang et al., 2011). The team of Academician Chen Jing of Yunnan University has carried out arsenic pollution control in Yangzonghai Lake since 2009 (Chen et al., 2015) by adopting the process of atomization spray of $\mathrm{FeCl}_{3}$ solution to remove arsenic from lake water. According to reports, the water quality of Yangzonghai Lake has been restored to Class III in November 2016. However, up to now, there is yet no detailed report on the status and variation trends of arsenic content in lakes and sediments after the treatment, and the stability of arsenic in sediments needs further investigation. Based on this, the author conducted systematic sampling and analysis of Yangzonghai Lake water and sediments in December 2016, found out the total amount and morphological composition of arsenic in lake water and sediment, and analyzed spatial distribution of arsenic in water bodies, sediments and sediment interstitial waters. Combining the sample analysis of 2008-2010 (Zhang et al., 2012), the variation trend and risk of arsenic were evaluated. This means important guiding significance for the further management of Yang Zonghai and the restoration of water environment.

\section{Materials and methods}

\section{Study area}

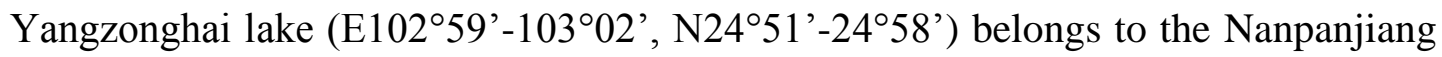
water system of the Pearl River Basin. The lake surface is spindle-shaped, $2.5 \mathrm{~km}$ wide from east to west, $12.7 \mathrm{~km}$ long from north to south, and $32.3 \mathrm{~km}$ long on the lakeshore. The drainage area is $286 \mathrm{~km}^{2}$, the lake area is $31.9 \mathrm{~km}^{2}$ (at water level $1770 \mathrm{~m}$ ), the deepest point is $29.1 \mathrm{~m}$, the water storage capacity is 604 million $\mathrm{m}^{3}$, and the water exchange period is 13 years (Chen, 2008). The nourishment source mainly comes from natural rainfall, Yangzong Great River and Qixing River catchment, artificial water of Baiyi River and underground water. The lake water flows into Nanpan River through the only outlet, Tangchi River.

\section{Sampling and analysis}

In December 2016, systematic sampling of lake water and sediment was carried out, as shown in Figure 1 and Table 1. A total of 19 water samples were taken and 120 groups of sediment samples were collected. In order to analyze the arsenic content in the lake water, 7 sampling points were arranged along the north-south axis of the lake center, and the sampling numbers were S01-S07. Using the "MEGA-MONSOON sampling pump" produced in the United States, water samples of 0.5, $10 \mathrm{~m}$ depth were collected at S01 and S07, water samples of 0.5, 10, and $20 \mathrm{~m}$ depth were collected at S02-S06. The samples were stored in a $250 \mathrm{ml}$ plastic bottle and a total of 19 samples were taken. To analyze the content and morphological characteristics of arsenic in the sediment, an average of 30 sampling points were arranged in the lake. Sample collection and stratification were performed using the "LENZ type sediment sampler" produced by HYDRO-BIOS, Germany. For each sampling point, 1-layer sample was taken from the top to the bottom at $2 \mathrm{~cm}$ intervals and 4 layers were taken. The samples were placed in a plastic ziplock bag and sealed for preservation, and 120 groups of samples were taken.

After the water samples were collected, the "Hash multi-parameter field test box" was used to quickly measure the indicators like $\mathrm{pH}$ value, conductivity, dissolved 
oxygen on the site; the collected water sample was filtered by a $0.45 \mu \mathrm{m}$ disposable pinhole filter, added with $1 \%$ volume of $\mathrm{HNO}_{3}$ with a concentration of $1: 1$ for total arsenic analysis. The samples were sent to the Guangdong Province Material Testing Center for testing. After the sediment samples were collected, they were divided into 2 parts, one of which was dried in shade in the laboratory, removed with animal and plant residues and stones, ground, screened through a 200 mesh nylon sieve, and analyzed for arsenic and its seven binding fraction (including water soluble fraction, ion exchange fraction, carbonate fraction, oxide fraction, humic acids fraction, strong organic fraction, residual fraction) (Liu et al., 2018); for the other one, interstitial water was prepared using "centrifugation method", and the sample was placed in a plastic centrifuge cup, centrifuged at $5000 \mathrm{r} / \mathrm{min}$ for $20 \mathrm{~min}$, with upper layer interstitial water taken for analysis of indicators like total arsenic. The test of sediment and interstitial water was completed by Guangdong Province Material Testing Center.

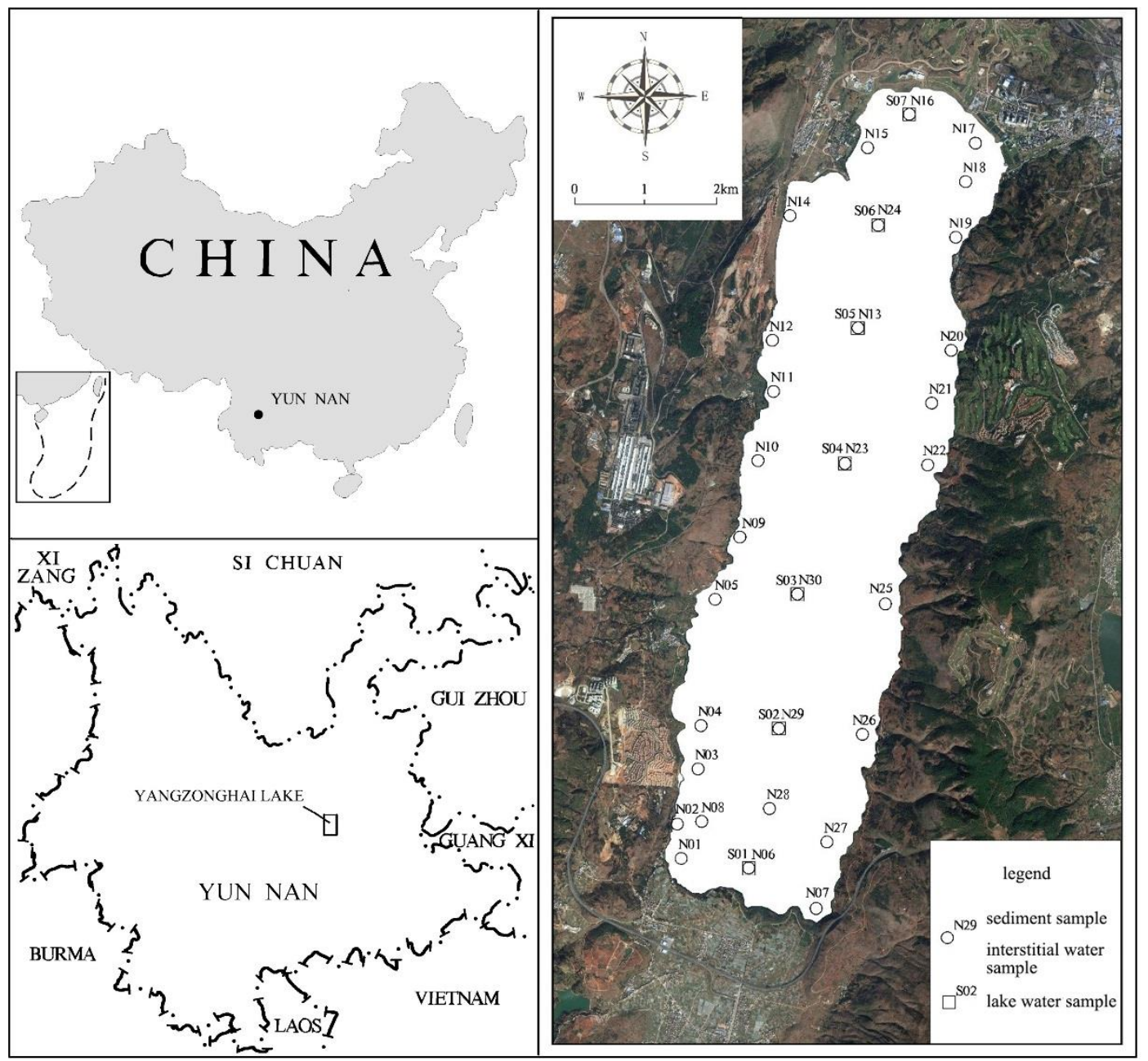

Figure 1. Sampling points

The descriptive statistical parameters were calculated with Microsoft Office Excel 2016. The positions of sample locations were recorded as a coordinate system using a GPS receiver. The kriging interpolations of the contaminant concentrations were computed with the MapGIS 6.7. 
Table 1. GPS coordinates of the sampling points

\begin{tabular}{|c|c|c|c|c|c|}
\hline Sampling points & \multicolumn{2}{|c|}{ GPS coordinates } & Sampling points & \multicolumn{2}{|c|}{ GPS coordinates } \\
\hline N01 & $102^{\circ} 58^{\prime} 57^{\prime \prime}$ & $24^{\circ} 52^{\prime} 01^{\prime \prime}$ & N16 (S07) & $103^{\circ} 00^{\prime} 46^{\prime \prime}$ & $24^{\circ} 57^{\prime} 45^{\prime \prime}$ \\
\hline N02 & $102^{\circ} 58^{\prime} 54^{\prime \prime}$ & $24^{\circ} 52^{\prime} 17^{\prime \prime}$ & N17 & $103^{\circ} 01^{\prime} 19^{\prime \prime}$ & $24^{\circ} 57^{\prime} 32^{\prime \prime}$ \\
\hline N03 & $102^{\circ} 59^{\prime} 04^{\prime \prime}$ & $24^{\circ} 52^{\prime} 42^{\prime \prime}$ & N18 & $103^{\circ} 01^{\prime} 15^{\prime \prime}$ & $24^{\circ} 57^{\prime} 14^{\prime \prime}$ \\
\hline N04 & $102^{\circ} 59^{\prime} 05^{\prime \prime}$ & $24^{\circ} 53^{\prime} 02^{\prime \prime}$ & N19 & $103^{\circ} 01^{\prime} 10^{\prime \prime}$ & $24^{\circ} 56^{\prime} 49^{\prime \prime}$ \\
\hline N05 & $102^{\circ} 59^{\prime} 12^{\prime \prime}$ & $24^{\circ} 54^{\prime} 00^{\prime \prime}$ & $\mathrm{N} 20$ & $103^{\circ} 01^{\prime} 08^{\prime \prime}$ & $24^{\circ} 55^{\prime} 57^{\prime \prime}$ \\
\hline N06 (S01) & $102^{\circ} 59^{\prime} 31^{\prime \prime}$ & $24^{\circ} 51^{\prime} 57^{\prime \prime}$ & N21 & $103^{\circ} 00^{\prime} 59^{\prime \prime}$ & $24^{\circ} 55^{\prime} 32^{\prime \prime}$ \\
\hline N07 & $103^{\circ} 00^{\prime} 05^{\prime}$ & $24^{\circ} 51^{\prime} 39^{\prime \prime}$ & $\mathrm{N} 22$ & $103^{\circ} 00^{\prime} 58^{\prime \prime}$ & $24^{\circ} 55^{\prime} 04^{\prime \prime}$ \\
\hline N08 & $102^{\circ} 59^{\prime} 07^{\prime \prime}$ & $24^{\circ} 52^{\prime} 18^{\prime \prime}$ & N23 (S04) & $103^{\circ} 00^{\prime} 16^{\prime \prime}$ & $24^{\circ} 55^{\prime} 04^{\prime \prime}$ \\
\hline N09 & $102^{\circ} 59^{\prime} 24^{\prime \prime}$ & $24^{\circ} 54^{\prime} 29^{\prime \prime}$ & N24 (S06) & $103^{\circ} 00^{\prime} 31^{\prime \prime}$ & $24^{\circ} 56^{\prime} 54^{\prime \prime}$ \\
\hline N10 & $102^{\circ} 59^{\prime} 32^{\prime \prime}$ & $24^{\circ} 55^{\prime} 04^{\prime \prime}$ & N25 & $103^{\circ} 00^{\prime} 37^{\prime \prime}$ & $24^{\circ} 53^{\prime} 59^{\prime \prime}$ \\
\hline N11 & $102^{\circ} 59^{\prime} 39^{\prime \prime}$ & $24^{\circ} 55^{\prime} 36^{\prime \prime}$ & N26 & $103^{\circ} 00^{\prime} 27^{\prime \prime}$ & $24^{\circ} 52^{\prime} 59^{\prime \prime}$ \\
\hline $\mathrm{N} 12$ & $102^{\circ} 59^{\prime} 39^{\prime \prime}$ & $24^{\circ} 56^{\prime} 00^{\prime \prime}$ & $\mathrm{N} 27$ & $103^{\circ} 00^{\prime} 10^{\prime \prime}$ & $24^{\circ} 52^{\prime} 09^{\prime \prime}$ \\
\hline N13 (S05) & $103^{\circ} 00^{\prime} 21^{\prime \prime}$ & $24^{\circ} 56^{\prime} 06^{\prime \prime}$ & $\mathrm{N} 28$ & $102^{\circ} 59^{\prime} 41^{\prime \prime}$ & $24^{\circ} 52^{\prime} 24^{\prime \prime}$ \\
\hline N14 & $102^{\circ} 59^{\prime} 46^{\prime \prime}$ & $24^{\circ} 56^{\prime} 58^{\prime \prime}$ & N29 (S02) & $102^{\circ} 59^{\prime} 45^{\prime \prime}$ & $24^{\circ} 53^{\prime} 01^{\prime \prime}$ \\
\hline N15 & $103^{\circ} 00^{\prime} 25^{\prime \prime}$ & $24^{\circ} 57^{\prime} 29^{\prime \prime}$ & N30 (S03) & $102^{\circ} 59^{\prime} 53^{\prime \prime}$ & $24^{\circ} 54^{\prime} 03^{\prime \prime}$ \\
\hline
\end{tabular}

\section{Results and analysis}

\section{Arsenic in lake water}

The $\mathrm{pH}$ value of the lake water is between 7.95-9.01, with an average of 8.69 , which is alkaline. There is no obvious regularity in the horizontal distribution. In the vertical distribution, the $\mathrm{pH}$ value decreases slightly as the water depth increases. The conductivity is between $442-524 \mu \mathrm{S} / \mathrm{cm}$, the average value is $463 \mu \mathrm{S} / \mathrm{cm}$, with relatively uniform distribution vertically. The dissolved oxygen is between 5.91-6.12 mg/L, with an average value of $6.07 \mathrm{mg} / \mathrm{L}$, which decreases slightly as water depth increases. The results of the 2010 survey showed that the average $\mathrm{pH}$ value of the lake water was 8.66, which also decreased slightly with the increase of water depth; the average conductivity was $456 \mu \mathrm{S} / \mathrm{cm}$, and the distribution was relatively uniform. It can be seen that in recent years, regardless of content or distribution characteristics, field indicator characteristics of the lake water show no significant changes and the overall characteristics of the lake water environment is relatively stable.

According to the results of this survey, the dissolved arsenic content in Yangzonghai Lake water ranges from 0.029 to $0.036 \mathrm{mg} / \mathrm{L}$, with an average of $0.033 \mathrm{mg} / \mathrm{L}$. According to the Surface Water Environmental Quality Standard (GB 3838-2002), it belongs to Class III water. In the vertical distribution, the arsenic content does not change much, but the arsenic content at the depth of $10 \mathrm{~m}$ is slightly higher than that of $0.5 \mathrm{~m}$ in the surface layer and $20 \mathrm{~m}$ in the bottom layer. The arsenic content at the depth of $10 \mathrm{~m}$ is more concentrated than that of $0.5 \mathrm{~m}$ and $20 \mathrm{~m}$, and the distribution difference is relatively small. In the horizontal distribution, from south to north, the arsenic content in each lake depth is basically reduced gradually. Among them, the maximum difference of arsenic content in the depth of $0.5 \mathrm{~m}$ is $0.007 \mathrm{mg} / \mathrm{L}$, the maximum difference of arsenic content in the depth of $10 \mathrm{~m}$ is $0.003 \mathrm{mg} / \mathrm{L}$, and the maximum difference of arsenic content in the depth of $20 \mathrm{~m}$ is $0.005 \mathrm{mg} / \mathrm{L}$, which also reflects that in the horizontal distribution, surface lake water and bottom lake water 
have relatively obvious distribution differences, and the arsenic content of lake water is stable at $10 \mathrm{~m}$ depth.

Previous studies have shown that the As content in the lake water in October 2008 ranged from 0.130 to $0.190 \mathrm{mg} / \mathrm{L}$ (Qi et al., 2010). By September 2009, the average content of As in lake water and sediment was $0.161 \mathrm{mg} / \mathrm{L}$ (Wang et al., 2011). By April 2010, the total As content in Yangzonghai water was $0.083 \mathrm{mg} / \mathrm{L}$ (Zhang et al., 2012). It can be seen that the arsenic content of Yangzonghai Lake reached a peak value in 2009 and gradually decreased thereafter. As of 2016, the arsenic content of lake water decreased to an average of $0.033 \mathrm{mg} / \mathrm{L}$, a decrease of about $78 \%$. In 2010 , there was a significant difference in the vertical distribution of arsenic in the lake. The arsenic content in the lower layer was significantly higher than that in the upper layer. However, there was no significant difference in the arsenic content of the lake in the vertical direction. This is due to the fact that the sampling in 2010 was during the control of spraying agents. In the flocculation and sedimentation process, the sedimentation of the lower layer of water is later than that of the upper layer of water, or the sedimentation effect is reduced as the action progresses. In this investigation, after the sedimentation process ended, the lake water was evenly mixed, which caused the phenomenon.

\section{Arsenic in interstitial water}

The arsenic content in $0-2 \mathrm{~cm}$ sediment interstitial water is between 0.0004$0.0629 \mathrm{mg} / \mathrm{L}$ and the average value is $0.0082 \mathrm{mg} / \mathrm{L}$. The arsenic content in the $2-4 \mathrm{~cm}$ sediment interstitial water is between $0.0006-0.0227 \mathrm{mg} / \mathrm{L}$ and the average value is $0.0042 \mathrm{mg} / \mathrm{L}$. The arsenic content in $4-6 \mathrm{~cm}$ sediment interstitial water is between $0.0004-0.0222 \mathrm{mg} / \mathrm{L}$ and the average value is $0.0038 \mathrm{mg} / \mathrm{L}$. The arsenic content in $6-$ $8 \mathrm{~cm}$ sediment interstitial water is between 0.0002 and $0.0170 \mathrm{mg} / \mathrm{L}$, and the average value is $0.0031 \mathrm{mg} / \mathrm{L}$.

The arsenic content in interstitial water is generally low. Except for the surface interstitial water of the N18 point, the arsenic content is less than $0.05 \mathrm{mg} / \mathrm{L}$ in all the samples, and the arsenic content of most samples is less than $0.005 \mathrm{mg} / \mathrm{L}$. As the depth increases, the average arsenic content decreases sharply. The arsenic content in the 0$2 \mathrm{~cm}$ layer is nearly twice that of the $2-4 \mathrm{~cm}$ layer, while the average arsenic content in the three layers below $2 \mathrm{~cm}$ decreases, but the variation is small. In terms of the distribution ratio, the proportion of samples with arsenic content less than $0.005 \mathrm{mg} / \mathrm{L}$ gradually increases, and the proportion of other ranges gradually decreases. By $4-6 \mathrm{~cm}$ and 6-8 cm, the proportion of arsenic content in different ranges has become stable. Comparison of the interstitial water arsenic content in each sampling point reveals that the vertical distribution of arsenic generally decreases with the increase of sediment depth, but the local area is also more complicated. The arsenic content of 17 points increases linearly with depth, and that of 6 points shows fluctuation state of increasing first and then decreasing. The two accounts for 3/4 of the total number of samples. There are 6 points with wavelike rises, only arsenic at one point rises linearly, and the two accounts for about 1/4 of the number of samples, as shown in Figure 2.

In the 0-2 cm interstitial water, the relatively high arsenic area is concentrated in two areas. One is Tangchi Town and Shijiazui area on the north shore. The arsenic content of the four sampling points in this area, N15, N16, N17 and N18, is above $0.01 \mathrm{mg} / \mathrm{L}$, and the number is the highest in point N18 $(0.0629 \mathrm{mg} / \mathrm{L})$. The other is located near the N30 point in the south of the lake center, where the relatively high arsenic distribution 
is only caused by $\mathrm{N} 30(0.0219 \mathrm{mg} / \mathrm{L})$, and the distribution range is small. Arsenic content in other areas is generally low, basically within $0.005 \mathrm{mg} / \mathrm{L}$. In $2-4 \mathrm{~cm}$ pore water, the arsenic content is obviously lower than that of the upper layer, and the relatively high value points are concentrated in the north shore area. Here, the arsenic content of the four sampling points is still above $0.01 \mathrm{mg} / \mathrm{L}$, and the highest value point is changed from N18 to N15 $(0.0227 \mathrm{mg} / \mathrm{L})$. However, high value area of the lake center has disappeared, the arsenic content in the whole lake area is basically less than $0.004 \mathrm{mg} / \mathrm{L}$, and arsenic content in some areas is below $0.002 \mathrm{mg} / \mathrm{L}$. In the $4-6 \mathrm{~cm}$ interstitial water, the relatively high value points are concentrated in two areas. One is still near the north shore, but the area with figure larger than $0.01 \mathrm{mg} / \mathrm{L}$ has been reduced. It is mainly concentrated around N15 and N18, and the highest value still appears in N15 $(0.0222 \mathrm{mg} / \mathrm{L})$. The other area appears in the 30-mu area of the West Bank, with a small distribution range concentrated around N11 point carrying arsenic content of $0.0154 \mathrm{mg} / \mathrm{L}$. Except the two areas, the arsenic content in other areas is basically within $0.004 \mathrm{mg} / \mathrm{L}$, and the area with a figure below $0.002 \mathrm{mg} / \mathrm{L}$ is further expanded. In the $6-8 \mathrm{~cm}$ interstitial water, the relatively high value points are concentrated only in the north shore area. The arsenic content of the three sampling points of N15, N16 and N18 is above $0.01 \mathrm{mg} / \mathrm{L}$, and the highest value point is still N15 $(0.0170 \mathrm{mg} / \mathrm{L})$. The arsenic content of other areas drops to within $0.002 \mathrm{mg} / \mathrm{L}$, as shown in Figure 3.

\section{Arsenic in sediment}

The determination of arsenic in the sediment shows that the arsenic content of the 0 $2 \mathrm{~cm}$ sediment is between $16.2-230.0 \mathrm{mg} / \mathrm{kg}$, with an average of $50.5 \mathrm{mg} / \mathrm{kg}$ and a coefficient of variation of $94 \%$. The arsenic content in $2-4 \mathrm{~cm}$ sediment interstitial water is between $15.1-136.0 \mathrm{mg} / \mathrm{kg}$, with an average of $40.1 \mathrm{mg} / \mathrm{kg}$ and a coefficient of variation of $76 \%$. The arsenic content in $4-6 \mathrm{~cm}$ sediment interstitial water is between $11.7-96.4 \mathrm{mg} / \mathrm{kg}$, with an average of $33.6 \mathrm{mg} / \mathrm{kg}$ and a coefficient of variation of $62 \%$. The arsenic content in 6-8 cm sediment interstitial water is between $11.8-148.0 \mathrm{mg} / \mathrm{kg}$, with an average of $32.5 \mathrm{mg} / \mathrm{kg}$ and a coefficient of variation of $79 \%$. Samples with an arsenic content of less than $25 \mathrm{mg} / \mathrm{kg}$ are substantially uncontaminated, and the proportion of samples in each layer ranges from $37 \%$ to $60 \%$, with the ratio from top to bottom significantly increased, as shown in Figure 4. The sample with arsenic content between $25-50 \mathrm{mg} / \mathrm{kg}$ is slightly polluted, and the proportion of samples in each layer is between $27 \%$ and $37 \%$, with the proportion of $0-6 \mathrm{~cm}$ basically unchanged and that $6-8 \mathrm{~cm}$ decreased to some extent. The samples with arsenic content between 50$100 \mathrm{mg} / \mathrm{kg}$ are moderately polluted, and the proportion of samples in each layer is between $10 \%-17 \%$, showing wavelike decrease from top to bottom. The samples with arsenic content higher than $100 \mathrm{mg} / \mathrm{kg}$ is heavily polluted, and the proportion of samples in each layer is between $0 \%-10 \%$, showing wavelike decrease of first decrease and then increase from top to bottom and the amplitude is big. It can be seen that as the sampling depth increases, arsenic content in the sediment gradually decreases on the whole, and the heavily polluted sediment is still mainly distributed in the surface layer.

Arsenic in the sediment has very obvious difference in horizontal distribution. The high arsenic area is mainly distributed in Tangeying, Xinjie of south shore and Sanying and Tangchi town of north shore. The arsenic content is generally above $50 \mathrm{mg} / \mathrm{kg}$, and the arsenic content in the central area of the lake is relatively low. Generally, it is lower than $25 \mathrm{mg} / \mathrm{kg}$, and characteristics of gradually spreading to the lake center along the 
pollution source on the shore are demonstrated in overall, and there is obvious pollution halo characteristic, as shown in Figure 5.

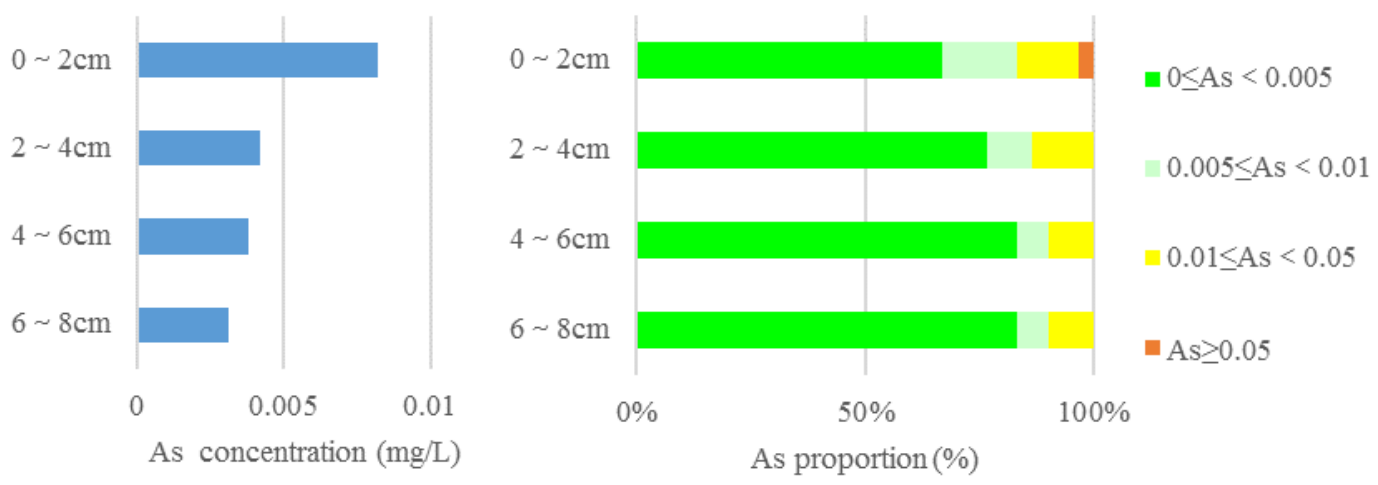

Figure 2. Average content and proportion of arsenic in interstitial water

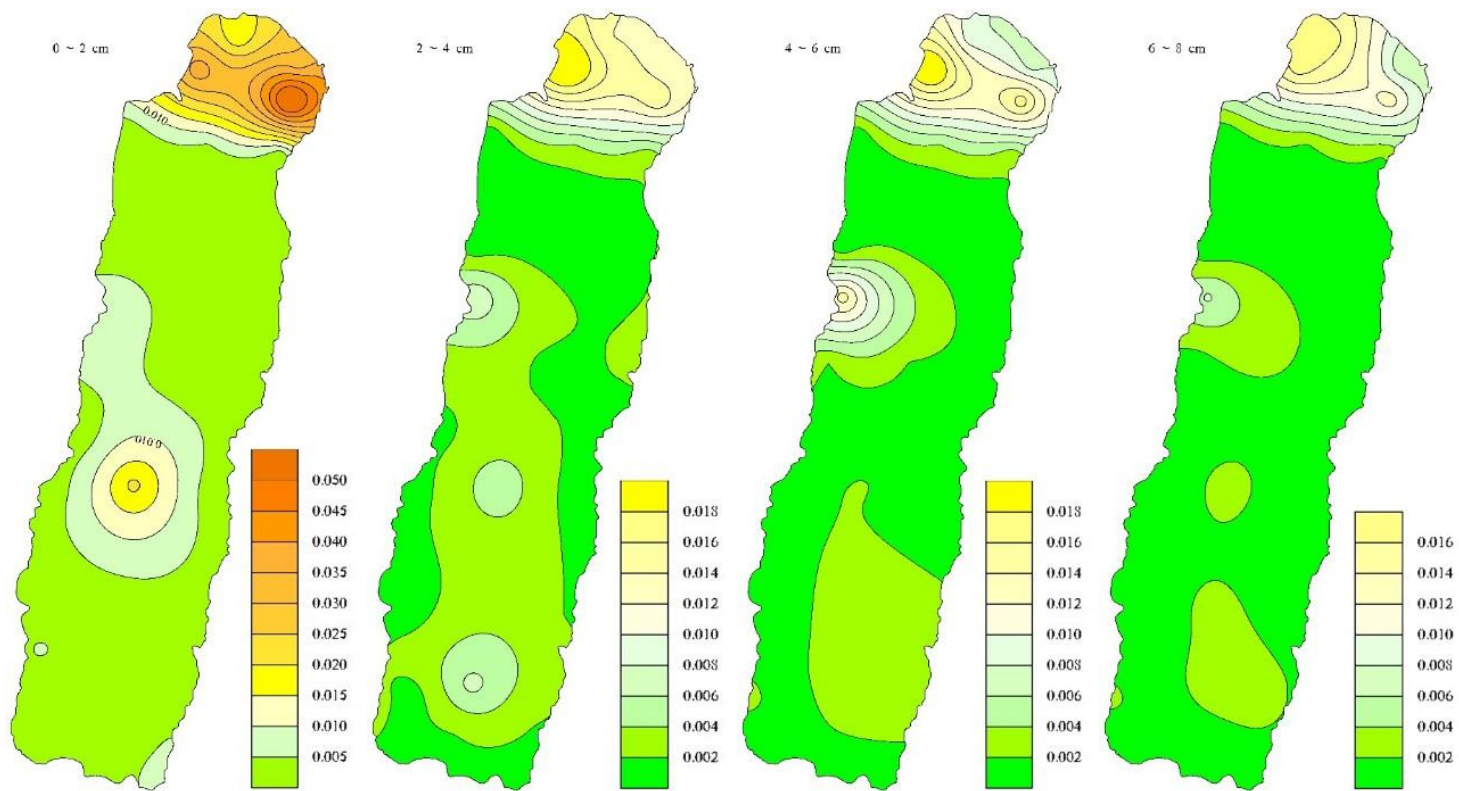

Figure 3. Distribution of arsenic content in interstitial water $(\mathrm{mg} / \mathrm{L})$

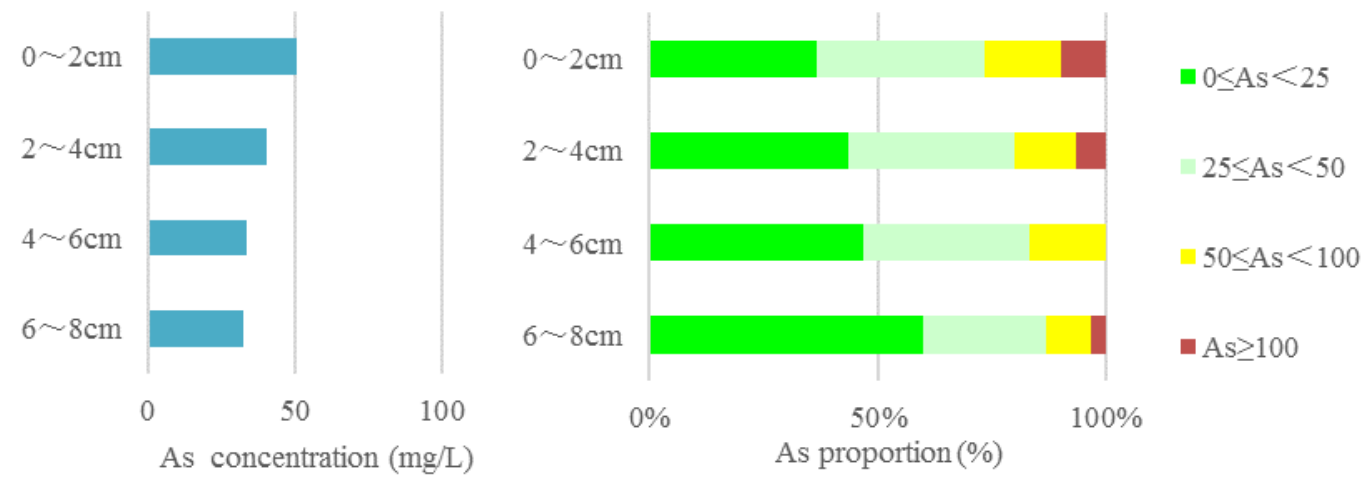

Figure 4. Average content and proportion of arsenic in sediment $(\mathrm{mg} / \mathrm{L})$ 

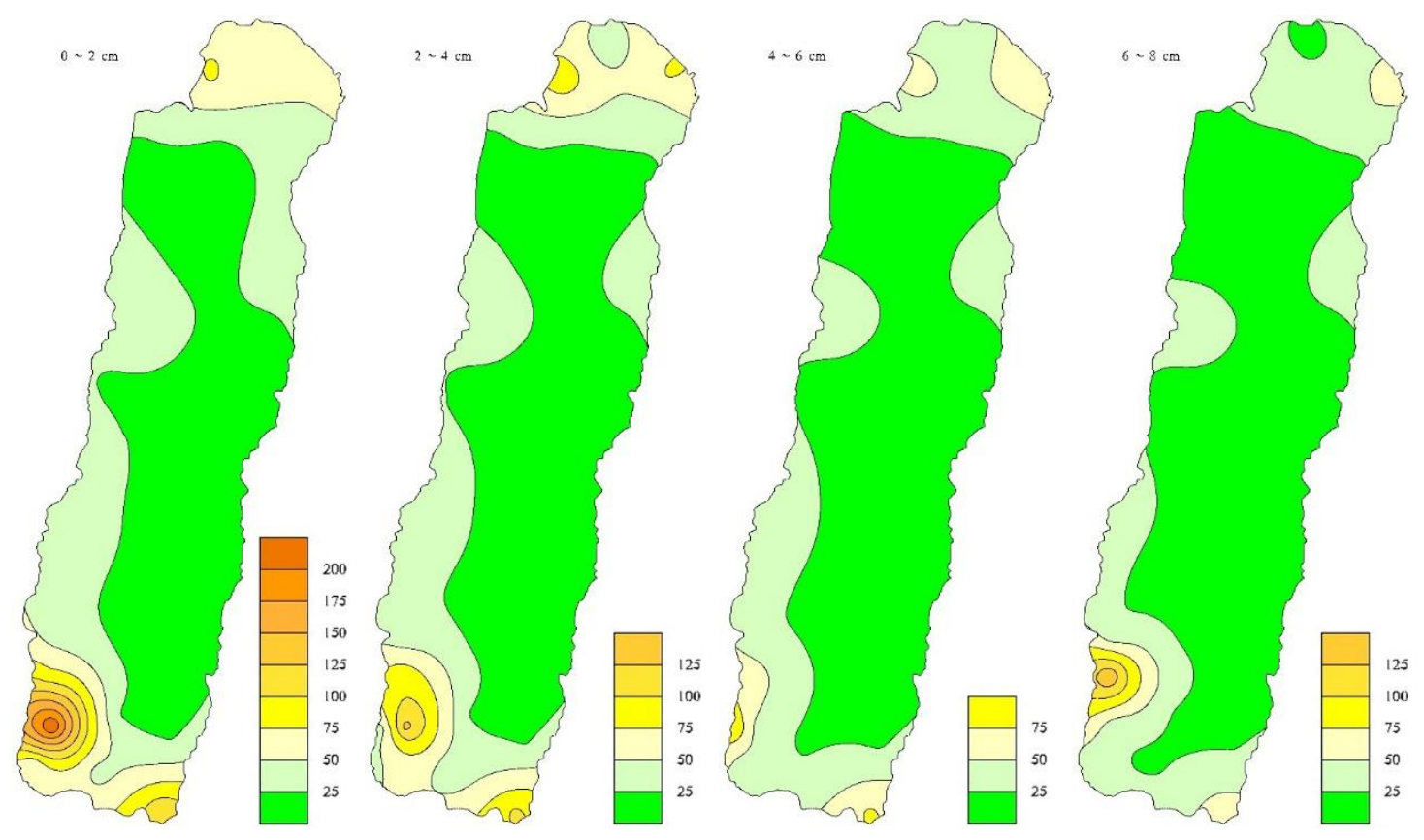

Figure 5. Spatial distribution of arsenic content in sediments $(\mathrm{mg} / \mathrm{kg})$

Specifically, in the 0-2 $\mathrm{cm}$ sediment, the area with the highest arsenic content is located at N08, N02, N03 points near Tangeying and N07 point near Xinjie, and the arsenic content is $230 \mathrm{mg} / \mathrm{kg}$ and $164 \mathrm{mg} / \mathrm{kg}, 85.4 \mathrm{mg} / \mathrm{kg}$ and $121 \mathrm{mg} / \mathrm{kg}$, respectively, followed by Tangchi Town of north shore where the arsenic content of N15, N16 and $\mathrm{N} 17$ points in the coastal areas is $77.9 \mathrm{mg} / \mathrm{kg}, 66.8 \mathrm{mg} / \mathrm{kg}$ and $74.3 \mathrm{mg} / \mathrm{kg}$, respectively. In the $2-4 \mathrm{~cm}$ sediment, the high arsenic distribution area on both the north and south shores decreases to different extents. The arsenic content of N08 point in Tangeying is still the highest, being $136 \mathrm{mg} / \mathrm{kg}$, followed by that of N07 point of Xinjie and the content is $104 \mathrm{mg} / \mathrm{kg}$. The high arsenic area in north shore is reduced to the vicinity of Sanying N15 point and Tangchi N17 point, and the arsenic content is $92.9 \mathrm{mg} / \mathrm{kg}$ and $77.9 \mathrm{mg} / \mathrm{kg}$, respectively. In the 4-6 cm sediment, the high arsenic zone is once again reduced and concentrated around Tangeying N02, Xinjie N07, Sanying N15 and Tangchi N17 points, with arsenic content being $96.4 \mathrm{mg} / \mathrm{kg}, 77.8 \mathrm{mg} / \mathrm{kg}, 62.9 \mathrm{mg} / \mathrm{kg}$ and $70.9 \mathrm{mg} / \mathrm{kg}$, respectively. In the $6-8 \mathrm{~cm}$ sediment, the arsenic content in the vicinity of Tangeying increases, increasing to $148 \mathrm{mg} / \mathrm{kg}$ at N03 point, while area of other high arsenic zones continues to shrink, and the arsenic content in most of the lake area is maintained within $25 \mathrm{mg} / \mathrm{kg}$.

Previous studies have shown that the arsenic content in the sediment at the end of October 2008 ranged from 54.86 to $193.29 \mathrm{mg} / \mathrm{kg}$ (Qi et al., 2010). By September 2009, the average content of arsenic in the sediment was $46.96 \mathrm{mg} \cdot \mathrm{kg}^{-1}$ (Wang et al., 2011). The data in 2010 showed that the arsenic content in the sediment increased to 6.05$396.49 \mathrm{mg} / \mathrm{kg}$, and the average content of As in the 0-2, 2-4, 4-6 and 6-8 cm sediments was $155.66 .52 .01,29.78,19.22 \mathrm{mg} / \mathrm{kg}$, respectively (Zhang et al., 2012). On the one hand, the arsenic content in the sediments of each layer in this sampling has dropped significantly, and the surface arsenic content has the largest decline, which is about 1/4 of the 2010 test data. Due to the implementation of arsenic treatment by sedimentation, the sedimentation process resulted in a higher arsenic content in the sediment at the end 
of 2010. After 2014, the arsenic content of the sediment decreases quite obviously, and the arsenic content in the lake water does not rise, indicating that the arsenic in the sediment is less likely to be reversely dissolved into the lake water. On the other hand, the vertical distribution characteristics of the sediment are gradually complicated. At the end of 2010, the vertical distribution of sediment arsenic content decreased significantly with depth. The maximum value of arsenic appears in the surface sediment. Only the maximum arsenic content at 2 points appears in the lower sediment. The arsenic content of these two points is generally low, both lower than $20 \mathrm{mg} / \mathrm{kg}$, and the difference in arsenic content between the layers is extremely small, which basically reflects the natural deposition state. In this sampling result, the maximum arsenic content of 11 points appears in the lower sediment, and the maximum arsenic content of 5 points appears in the $6-8 \mathrm{~cm}$ sediment.

The decrease in the total arsenic amount in the sediment and the abnormal distribution of arsenic in each layer found in this investigation may be caused by the following reasons: Affected by the arsenic removal and sedimentation process, as the arsenic content in the lake water decreases, the arsenic content in sedimentation particles is also reduced, then the low arsenic sediment covers the previous high arsenic sediment; The migration of sediment arsenic to the lower layer or surrounding sediment under the disturbance of lake water; Under the disturbance of the lake water, the sediment agitation phenomenon appears.

Arsenic exists in different binding states in the sediment and shows different mobility, bioavailability and ecotoxicity (Desbarats et al., 2017; Hossain et al., 2016). The mass fractions of water soluble fraction, ion exchange fraction and carbonate fraction are relatively low, and the sum of the three accounts for $0.55 \%$ of the total amount on average, and there is almost no change in the vertical distribution. Arsenic in water soluble fraction, ion exchange fraction and carbonate fraction is sensitive to environmental changes, which can be released under neutral conditions. Easy to migrate and transform, it can be absorbed by plants and carries high potential ecological risks (Zhou, 2017). The arsenic in oxide fraction accounts for $6.82 \%$ of the total amount on average, up to $27.20 \%$ at the highest, and the proportion decreases with increase of depth in the vertical distribution. This form is a wrapped or precipitated part of arsenic linked to iron-manganese oxide, which belongs to a strong ion bonding chemical form. It is not easily released under stable external conditions, but when the water body has a reduced redox potential or is in hypoxia, this bound arsenic may be reduced to a bioavailable state (Wang et al., 2015). The humic acid fraction and strong organic fraction are mainly chelated by organic matter such as animal and plant residues, humus and arsenic in the sediment. When the external conditions change little, the arsenic in this state is relatively stable, which has small environmental hazard. The sum of the two accounts for $8.97 \%$ on average, up to $23.25 \%$ at the highest, and the proportion also decreases with the increase of depth in the vertical distribution. The residual state is mainly present in the crystal lattice of primary minerals and secondary silicate minerals. It is very stable and does not participate in the rebalanced distribution of water-sediment systems (Huang et al., 2010, 2016a), which contributes little to migration and bioavailability of arsenic in sediments, so it is generally considered safe to the environment. The arsenic in the Yangzonghai sediment mainly exists in the form of residual fraction, with the average content accounting for $83.66 \%$ of the total, up to $93.79 \%$ at the highest, and the proportion increases with the increase of depth in the vertical distribution, as shown in Figure 6. 


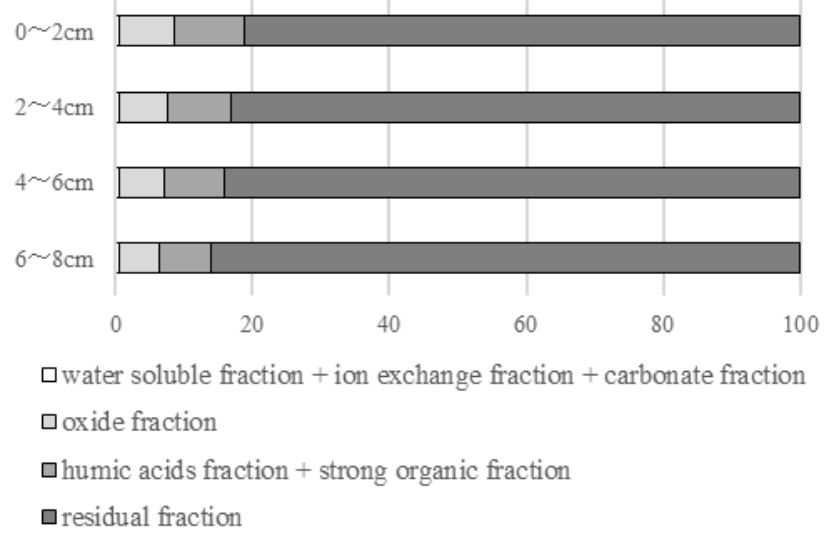

Figure 6. Ratio of different fraction of arsenic in sediments (\%)

According to the study in 2010, the proportion of residual arsenic in the 0-2, 2-4, 4-6 and $6-8 \mathrm{~cm}$ sediments was $58 \%, 65 \%, 69 \%$ and $78 \%$, respectively, which was increased to $81 \%, 83 \%, 84 \%$ and $86 \%$ respectively in this investigation. Meanwhile, content of arsenic in other forms decreased. It reflects that the form of arsenic in the sediment gradually changes to a more stable residual fraction over time. On the one hand, it is affected by the aging mechanism of arsenic in the soil (Huang et al., 2016b). On the other hand, flocculant used in the treatment work may also be one of the reasons for increased proportion of residual state arsenic in the sediment (Li et al., 2015).

In summary, the form of arsenic in the sediment is mainly in residual fraction, followed by the organic fraction and the oxide fraction, and the sum of the three accounts for more than $99 \%$ of the total amount. The content of water soluble fraction, ion exchange fraction and carbonate fraction is extremely low, and environmental influence is limited. The vertical distribution of various binding states of arsenic shows that with the continuous sedimentation process, the arsenic in the sediment gradually transforms from oxide fraction and organic fraction to the residual fraction. Therefore, in a more stable lake environment, the release of arsenic in the sediment is limited and the ecological risk is minimal.

Comparing the test results of interstitial water and sediment, it was found that there was no significant correlation between the two. The generation and direction of interstitial water are restricted and affected by various conditions, such as sediment pollution level, sedimentation physiochemical properties, redox conditions and hydrodynamic influence. The environment in Yangzonghai area is complex, and the total arsenic content in the sediment and arsenic content in various binding states do not determine the arsenic content in the interstitial water.

The vertical distribution characteristics of sediment interstitial water are often used to determine whether there is release of substance from the sediment to the lake (Wang et al., 2016). Generally speaking, if there is a phenomenon that substance in the sediment is released to the lake water, there is often a curve tendency that substance content increases first and then decreases as the depth increases. In this investigation, the arsenic content in the sediment interstitial water in most areas of Yangzonghai decreased significantly with the increase of sediment depth. Therefore, it can be inferred that there is no release of sediment arsenic into the lake water. 


\section{Conclusions}

In December 2016, the arsenic content of Yangzonghai Lake was between 0.029$0.036 \mathrm{mg} / \mathrm{L}$, with an average of $0.033 \mathrm{mg} / \mathrm{L}$. It has reached the Class III water standard, and the arsenic content is evenly distributed in different depths of the lake. The sediment interstitial water is weakly alkaline. The arsenic content in the interstitial water in Tangchi of north shore is relatively high, up to $0.0629 \mathrm{mg} / \mathrm{L}$ at the highest, while arsenic content in other areas is generally lower than $0.005 \mathrm{mg} / \mathrm{L}$, and the content is very small. Vertically, as the depth increases, the arsenic content mainly declines rapidly. The average content of arsenic in $0-2,2-4,4-6,6-8 \mathrm{~cm}$ sediments was $50.5 \mathrm{mg} / \mathrm{kg}, 40.1 \mathrm{mg} / \mathrm{kg}, 33.6 \mathrm{mg} / \mathrm{kg}$ and $32.5 \mathrm{mg} / \mathrm{kg}$, respectively. Horizontally, the high arsenic area is mainly distributed on both sides of the north and south shore, which gradually decreases from the coastal side toward the lake center. Vertically, as the depth increases, arsenic content in the sediment gradually decreases on the whole, and heavily polluted sediment is still mainly distributed in the surface layer. Morphological analysis shows that arsenic in the sediment is mainly in residual state, followed by organic matter binding state and iron-manganese oxide binding state, and the sum of the three accounts for more than $99 \%$ of the total amount. The water soluble fraction, ion exchange fraction and carbonate fraction are extremely low in content and has limited environmental impact. With the passage of time, the arsenic in the sediment gradually transforms from oxide fraction and organic fraction to residual fraction, tending to be more stable. That is to say, the lake treatment has achieved remarkable results, the release of arsenic in the sediment is limited, the possibility of reverse dissolution is small, and the ecological risk is minimal.

Acknowledgements. The study was financially supported by projects of China Geological Survey (No. DD20160308 and No. DD20190331).

\section{REFERENCES}

[1] Barrett, P. M., Hull, E. A., Burkart, K., Hargrave, O., McLean, J., Taylor, V. F., Jackson, B. P., Gawel, J. E., Neumann, R. B. (2019): Contrasting arsenic cycling in strongly and weakly stratified contaminated lakes: evidence for temperature control on sediment-water arsenic fluxes. - Limnology and Oceanography 64(3) 1333-1346.

[2] Bi, J. P., Liu, C., Li, S. Z. (2014): Variation of water quality of Yangzonghai Lake affected by arsenic pollution (in Chinese). - Water Resources Protection 30(1): 84-89.

[3] Chen, J., Zhang, S., Yang, X. J., Huang, Z. J., Wang, S. X., Wang, C., Wei, Q. Y., Zhang, G. L., Xiao, J. (2015): Arsenic Removal by Coagulation Process and the Field Expanding Experiments for Yangzonghai Lake (in Chinese). - Environmental Science 36(1): 202208.

[4] Chen, Y. J. (2008): Research on precaution and control of water pollution in Yangzong Lake (in Chinese). - Environmental Science Survey 27(3): 28-31.

[5] Desbarats, A. J., Pal, T., Mukherjee, P. K., Beckie, R. D. (2017): Geochemical evolution of groundwater flowing through arsenic source sediments in an aquifer system of West Bengal, India. - Water Resources Research 53(11): 8715-8735.

[6] Hossain, I., Anjum, N., Tasnim, T. (2016): Removal of arsenic from contaminated water utilizing tea waste. - International Journal of Environmental Science \& Technology 13(3): 843-848.

[7] Huang, G. X., Sun, J. C., Jing, J. H., Zhang, Y. X., Liu, J. T., Wang, J. C., Xiang, X. P., Chen, X., Cui, H. W. (2010): Distribution of arsenic in water and soil in the 
representative area of the Pearl River Delta (in Chinese). - Zhongshan Daxue Xuebao/Acta Scientiarum Natralium Universitatis Sunyatseni 49(1): 131-137.

[8] Huang, G. X., Chen, Z. Y., Wang, J., Hou, Q. X., Zhang, Y. (2016a): Impact of temperature on the aging mechanisms of arsenic in soils: fractionation and bioaccessibility. - Environmental Science and Pollution Research 23(5): 4594-4601.

[9] Huang, G. X., Chen, Z. Y., Zhang, Y., Liu, F., Wang, J., Hou, Q. (2016b): Changes of arsenic fractionation and bioaccessibility in wastewater-irrigated soils as a function of aging: Influence of redox condition and arsenic load. - Geoderma 280: 1-7.

[10] Huang, K., Liu, Y., Yang, C., Duan, Y., Yang, X., Liu, C. (2018): Identification of Hydrobiogeochemical processes controlling seasonal variations in arsenic concentrations within a riverbank aquifer at Jianghan Plain, China. - Water Resources Research 54(7): 4294-4308.

[11] Jakobsen, R., Kazmierczak, J., Sø, H. U., Postma, D. (2018): Spatial variability of groundwater arsenic concentration as controlled by hydrogeology: conceptual analysis using 2-D reactive transport modeling. - Water Resources Research 54(12): 1025410269.

[12] Li, Z. Y., Yang, C. L., Li, S. Y., Zhang, Y., Liu, R. B., Liu, K., Shen, S. L. (2015): Speciation and distribution of arsenic and its stability assessment in Lake Yangzonghai sediments after arsenic pollution remediation (in Chinese). - Environmental Science \& Technology 38(2): 41-47.

[13] Liu, G. N., Chen, M., Li, W. Q., Gong, W. W. (2018): A critical review on the speciation and development of sequential extraction procedures for arsenic in soils (in Chinese). Journal of Agro-Environment Science 37(12): 2629-2638.

[14] Qi, J. Y., Xu, Z. Y., Li, X. P., Fang, J. D., Huang, J. H. (2010): Study on source and speciation distribution characteristics of arsenic in Yangzonghai Lake waters (in Chinese). - Journal of Anhui Agricultural Sciences 38(20): 10789-10792.

[15] Romero-Freire, A., Sierra-Aragón, M., Ortiz-Bernad, I., Martín-Peinado, F. J. (2014): Toxicity of arsenic in relation to soil properties: implications to regulatory purposes. Journal of Soils \& Sediments 14(5): 968-979.

[16] Wang, J., Liu, F., Chen, Z. Y., Sun, J. C., Zhang, Y., Huang, G. X. (2015): Effect of sample pretreatment on the fractionation of arsenic in anoxic soils. - Environmental Science and Pollution Research 22(11): 8367-8374.

[17] Wang, W., Liu, X., Wang, Y., Guo, X., Lu, S. (2016): Analysis of point source pollution and water environmental quality variation trends in the Nansi Lake basin from 2002 to 2012. - Environmental Science and Pollution Research 23(5): 4886-4897.

[18] Wang, Z. H., He, B., Pan, X. J., Zhang, K. G., Wang, C., Sun, J., Yun, Z. J., Jiang, G. B. (2011): The levels, trends and risk assessment of arsenic pollution in Yangzonghai Lake, Yunnan (in Chinese). - Scientia Sinica Chimica 41(3): 556-564.

[19] Zhang, J., Li, T., Yang, Y. L., Liu, H. G., Wang, Y. Z. (2015): Erratum to: arsenic concentrations and associated health risks in Laccaria mushrooms from Yunnan (SW China). - Biological Trace Element Research 165(2)233-234.

[20] Zhang, Y. X., Xiang, X. P., Zhang, Y., Chen, X., Liu, J. T., Wang, J. C., Zhang, Y. J., Sun, J. C. (2012): Distribution and sources of arsenic in Yangzonghai Lake, China (in Chinese). - Environmental Science 33(11): 3768-3777.

[21] Zhou, X. (2017): Arsenic distribution and source in groundwater of Yangtze River Delta economic region, China. - Journal of Groundwater Science and Engineering 5(4): 343353. 